\title{
Feeding Management Strategy for Male Broiler Breeders and its Effects on Body Weight, Hatchability and Fertility
}

http://dx.doi.org/10.1590/1516-635x1604397-402

\section{-Author(s) \\ Silveira MM' \\ Freitas AG de ${ }^{\text {III }}$ \\ Moraes CA \\ Gomes FS' \\ Litz $\mathrm{FH}^{\prime}$ \\ Martins JMS \\ Fagundes NS \\ Fernandes EA"}

M.Sc. student of the Post-Graduation program in Veterinary Sciences, Universidade Federal de Uberlândia.

" PH.D., Professor of the Post-Graduation program in Veterinary Sciences, Universidade Federal de Uberlândia.

III Professor at Instituto Federal do Triângulo Mineiro- IFTM

Iv PH.D. student of the Post-Graduation program in Animal Science, Universidade Federal de Goiás.

$\checkmark$ PH.D. student of the Post-Graduation program in Animal Science and Pastures, ESALQ, Universidade de São Paulo.

\section{ABSTRACT}

The objective of the present study was to evaluate the supply of a specific-male diet on rooster body weight, hatchability, and fertility. Two diets were supplied during the egg production period: treatment 1, diet formulated for females and containing, in average, 2,830 kcal $\mathrm{ME} / \mathrm{kg}$ and $15 \% \mathrm{CP}$; and treatment 2, diet specifically formulated for male broiler breeders, containing 2,750 kcal ME/kg and $13.5 \% \mathrm{CP}$. In the experiment, 26 flocks, with approximately 7,000 females and 840 males each, belonging to the same broiler breeder commercial strain, were distributed into 26 houses $\left(1200 \mathrm{~m}^{2}\right)$ on the same farm, and submitted to the same management practices. Body weight was evaluated in 13 flocks per treatment and for five weeks $(45,50,55,60$, 65), and hatchability and fertility in four incubation lots per treatment and for the same weeks. Data were evaluated by the analysis of mixed models for repeated measurements, using the PROC MIXED of SAS 9.3 (SAS Institute Inc., Cary, NC, USA), and means were compared by the test of Tukey-Kramer at 5\% significance level. The specific-male diet allowed body weight control during all analyzed weeks and promoted high hatchability and egg fertility. The increase in the number of chicks hatched demonstrates the economic viability of feeding a specific diet for male broiler breeders.

\section{INTRODUCTION}

Global poultry production has grown and become more efficient, allowing offering chicken meat at competitive prices in the market. The continuous genetic improvement of broilers, particularly for rapid growth, better feed efficiency, and higher meat yield implies in constant changes in bird management and feeding. In broiler breeders, in particular, this means preventing the negative effects of excessive body weight on reproductive performance (Goerzen et al., 1996; Barbato, 1999; Romero-Sanchez et al., 2007).

The heritability of reproductive efficiency characteristics is relatively low and therefore, non-genetic factors, such as nutrition, have a stronger influence on broiler breeder performance (Reddy \& Kelly, 1991).

According to Borges et al. (2006a), the nutritional management of female broiler breeders has received more attention compared with males. Although males comprise only $10 \%$ of a flock, they represent $50 \%$ of the genetics of the chicks and are essential for fertility. In the 1980s, males and females started to be fed separately, although some companies still use the same feed for both sexes (Fernandes \& Fagundes, 2013).

The fertility of broiler breeder flocks declines during the last phase of their reproductive life (Creel et al., 1990; Walsh \& Brake, 1997). This 

Gomes FS, Litz FH, Martins JMS,

Fagundes NS, Fernandes EA
Silveira MM, Freitas AG de, Moraes CA,

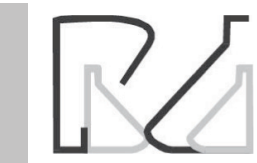

is mainly due to the progressive reduction of mating efficiency and frequency (Duncan et al., 1990), which has been attributed to excessive weight gain in males (Hocking, 1990; Hocking \& Bernard, 2000).

One of the biggest challenges faced by poultry production today is to extend the fertility of modern broiler breeders during the breeding period. The objective of the present study was to evaluate the effect of two diets supplied to male broiler breeders during egg production period: one formulated for females and the other specifically formulated for males, on male breeder body weight, and egg hatchability and fertility.

\section{MATERIAL AND METHODS}

\section{Birds, management, and diets}

This study was carried out at a broiler breeder farm located in the municipality of Monte Alegre de Minas, state of Minas Gerais, Brazil, between September of 2009 and December of 2010. Birds were housed in conventional open-sided houses with concrete floor. Birds were submitted to commercial management, and all management procedures were standardized.

During the production period, houses were equipped with bell drinkers (one drinker/80 birds), automatic pan feeder for females $(15 \mathrm{~cm} /$ female) with male-exclusion grill $(60 \mathrm{~mm}$ vertical and $45 \mathrm{~mm}$ horizontal), trough feeder for males $(20 \mathrm{~cm} / \mathrm{male})$, ventilation fans (one every $10 \mathrm{~m}$ ), and foggers (two longitudinal lines for the entire house length).

Broiler breeder flocks were fed a controlled feed allowance during the breeding period. Rooster feed allowance followed the recommendations of the COBB-500 manual. Breeding started when birds were 22 weeks old. A photoperiod of $16 \mathrm{~h}$ of light was applied.

In the experiment, 26 flocks, with approximately 7000 females and 840 males each, belonging to the same broiler breeder commercial strain, were distributed into 26 houses $\left(1200 \mathrm{~m}^{2}\right)$ on the same farm. The treatments consisted of two diets supplied to roosters during the egg production period: one was formulated for females (treatment 1) and the other was specifically formulated for males (treatment 2). Thirteen flocks were analyzed per treatment.

The nutritional levels of the rearing diet (week 1-4) and of the development 1 diet (week 5-16) were applied to both treatments (Table 1). Treatment 1 birds were fed a development 2 diet between weeks 17 and 22 , whereas the males in treatment 2 continued to be fed the development 1 diet up to week 27 (Table 1).
Feeding Management Strategy for Male Broiler Breeders and its Effects on Body Weight, Hatchability and Fertility

Table 1 - Nutritional levels of the rearing feed, development 1 and 2 diets.

\begin{tabular}{lccc}
\hline Nutrients & Rearing feed & Development 1 & Development 2 \\
\hline Energy (kcal ME/kg) & 3,000 & 2,800 & 2,850 \\
\hline Crude Protein (\%) & 19.50 & $15.00-15.50$ & 15.50 \\
\hline $\begin{array}{l}\text { Calcium (\%) } \\
\text { min./max. }\end{array}$ & $0.90-1.00$ & $1.00-1.10$ & $1.30-1.50$ \\
\hline Phosphorus (\%) & 0.48 & 0.44 & 0.43 \\
\hline
\end{tabular}

During the breeding period, treatment 1 males and females and treatment 2 females were fed four different diets, containing different nutritional levels (Table 2).

Table 2 - Nutritional levels of the breeding diets.

\begin{tabular}{lcccc}
\hline Nutrients & $\begin{array}{c}\text { Breeding 1 } \\
\text { (weeks } \\
23-34)\end{array}$ & $\begin{array}{c}\text { Breeding 2 } \\
\text { (weeks } \\
35-45)\end{array}$ & $\begin{array}{c}\text { Breeding 3 } \\
\text { (weeks } \\
46-64)\end{array}$ & $\begin{array}{c}\text { Breeding 4 } \\
\text { (after } \\
\text { week 65) }\end{array}$ \\
\hline $\begin{array}{l}\text { Energy } \\
\text { (kcal ME/kg) }\end{array}$ & 2,850 & 2,830 & 2,800 & 2,740 \\
\hline Crude Protein (\%) & 15.50 & 15.00 & 15.00 & 14.00 \\
\hline $\begin{array}{l}\text { Calcium (\%) } \\
\text { min./max. }\end{array}$ & $3.10-3.30$ & $3.30-3.50$ & $3.30-3.50$ & $3.50-3.70$ \\
\hline Phosphorus (\%) & 0.43 & 0.42 & 0.39 & $0.37-0.39$ \\
\hline
\end{tabular}

Treatment 2 males received only two different diets during the egg production period. Development diet 1 (Table 1) was supplied between week 5 and the beginning of the breeding period (week 27), after which (week 28) a rooster diet was supplied (Table 3). All diets were in the mash form, except for the rearing feed, which was pelleted.

Table 3 - Nutritional levels of the rooster diet.

\begin{tabular}{lc}
\hline Nutrients & $\begin{array}{c}\text { Rooster diet } \\
\text { (after week 28) }\end{array}$ \\
\hline Energy (kcal ME/kg) & 2,750 \\
\hline Crude Protein (\%) & 13.50 \\
\hline Calcium (\%) min./max. & $0.95-1.05$ \\
\hline Phosphorus (\%) & 0.40 \\
\hline
\end{tabular}

Male body weight, hatchability, and egg fertility were evaluated when males were $45,50,55,60$, and 65 weeks of age.

\section{Body weight evaluation}

Males were weighed, using a 50-g precision scale, in the afternoon, always at the same time, during the five weeks mentioned above. Twenty roosters from each flock were marked with non-toxic paint on the back to allow their easy identification, and with numbered leg bands to enable tracking individual weight. Thirteen flocks (replicates) per treatment were evaluated and average body weight was weekly calculated. Body 
weight was determined for 20 roosters per replicate in 13 replicates (flocks) for five weeks, totaling 1,300 roosters per treatment.

\section{Hatchability evaluation}

Eggs were sent to a hatchery in the city of Uberlândia, state of Minas Gerais, Brazil. Eggs from both treatments were stored between two and five days, incubated in multiple-stage Petersime incubators, and submitted to the same standardized incubation management and conditions. Hatchability was calculated as the average percentage of chicks hatched per week.

An incubation lot consisted of one, two, or more egg lots derived from a same farm. Four incubation lots (replicates), consisting of 11 egg lots, were chosen for the analysis of hatchability of treatment 1 , and four incubation lots (replicates), consisting of eight egg lots, were selected in treatment 2 . In total, 2,014,504 eggs were evaluated for hatchability.

\section{Egg fertility evaluation}

Infertile eggs were detected by embryo diagnosis, which was performed in five trays from the same incubation lot of the eggs that did not hatch after 21 days of incubation. The trays were located in the upper, middle, and lower part of the hatcher.

Eggs were individually broken, and care was taken to preserve the embryo, allowing the determination of the stage when embryo development stopped. Infertile eggs present the blastodisc as a single spot on the yolk, whereas fertile eggs present the blastoderm, i.e., the spot on the yolk and a halo around it (Adda, 2003). The weekly average of infertile eggs was calculated.

The same four incubation lots (replicates) per treatment used for hatchability analysis were utilized for fertility analysis. In total, 267,100 eggs were evaluated for fertility.

\section{Statistical analysis}

Data were evaluated by analysis of mixed models for repeated measures, considering the effects of treatment and age and their interaction, and five types of matrix structures of variance and covariance, using the PROC MIXED of SAS 9.3 (SAS Institute Inc., Cary, NC, USA). The structure used in the analysis tool was based on the lowest value of the Akaike
Information Criterion (AIC). Means were compared by the test of Tukey-Kramer at 5\% significance level.

\section{RESULTS AND DISCUSSION}

There was no significant interaction between treatment and week when rooster body weight and egg hatchability and fertility (Table 4) were analyzed.

The roosters fed the specific male diet (treatment $2)$ presented statistically lower body weight $(p<0.05)$, independently of week, compared with treatment 1 males (Table 4), indicating better body weight control was achieved. This is considered a favorable result, because there is a negative genetic correlation between weight gain and reproduction characteristics (Reddy \& Kelly, 1991). Weight gain increased with age in both treatments, as expected (Table 4).

The hatchability of eggs derived from males fed the specific male broiler breeder diet (treatment 2) was statistically higher $(p<0.05)$ than those from treatment 1 during all evaluated weeks, as shown in Table 4. The best hatchability was obtained in week 45 and the worst was observed in week 65, independently of treatment, as expected (Table 4).

The percentage of infertile eggs derived from treatment 2 roosters was statistically lower $(p<0.05)$ compared with treatment 1 , independently of week. The highest egg infertility percentage was observed in the last week analyzed (week 65) in both treatments (Table 4). Hocking (1990) observed that a low protein diet was associated with higher fertility, particularly during the latter part of the breeding period (49-60 weeks).

The specific male diet (treatment 2) metabolizable energy levels compared with the female diet (treatment

Table 4 - Average body weight of male broiler breeders and egg hatchability and infertility, considering the effects of treatments and weeks.

\begin{tabular}{lcccc}
\hline & & Weight gain $(\mathrm{kg})$ & Hatchability $(\%)$ & Egg infertility (\%) \\
\hline Treatments & 1 (female diet) & $5.211 \mathrm{a}$ & $77.27 \mathrm{~b}$ & $4.48 \mathrm{a}$ \\
Weeks & 2 (specific male diet) & $4.895 \mathrm{~b}$ & $81.44 \mathrm{a}$ & $3.01 \mathrm{~b}$ \\
& 45 & $4.907 \mathrm{~b}$ & $86.38 \mathrm{a}$ & $2.47 \mathrm{~b}$ \\
& 50 & $4.985 \mathrm{~b}$ & $83.94 \mathrm{ab}$ & $2.90 \mathrm{~b}$ \\
& 55 & $5.068 \mathrm{ab}$ & $80.90 \mathrm{~b}$ & $3.73 \mathrm{~b}$ \\
\hline CV $(\%)$ & 60 & $5.140 \mathrm{a}$ & $76.69 \mathrm{c}$ & $3.81 \mathrm{~b}$ \\
P-value & 65 & $5.166 \mathrm{a}$ & $68.88 \mathrm{~d}$ & $5.81 \mathrm{a}$ \\
& & 6.12 & 8.96 & 49.96 \\
\hline
\end{tabular}

Means followed by different letters in the same column are different by the test of Tukey $(p<0.05)$. 
1), therefore allowing better control of rooster body weight, and consequent higher hatchability and lower infertile egg percentage $(p<0.05)$. Romero-Sanchez et al. (2004) observed that low-density male broiler breeder diets, that is, with low crude protein and metabolizable energy levels, promoted good fertility. Low-density feeds have been frequently used to control broiler breeders' body weight (Leeson \& Summers, 2000).

In the present study, the dietary energy level of the rooster diet (treatment 2) was the same as that recommended by Rostagno et al. (2011); however, Borges et al. (2006a) suggested that a lower energy level $(2,660 \mathrm{kcal} \mathrm{ME} / \mathrm{kg})$ should be applied. The results also show that body weight was directly and positively correlated with energy intake, as previously demonstrated by Sexton et al. (1989). Excessive energy is mainly stored as body fat, increasing body weight and reducing both hatchability and fertility (Pearson \& Herron, 1981; Leeson, 1999 and Borges et al., 2006a). As energy is the most expensive nutrient of feeds (Borges et al., 2006a), a specific male diet, containing energy levels, may reduce feeding costs and significantly improve reproductive efficiency.

Protein is the dietary nutrient that has the strongest effect on the reproduction indices of broiler breeder flocks (Borges et al., 2006b). The treatment 2 diet, which contained lower protein level, resulted in better body weight control and fertility, in agreement with North \& Bell (1990). Romero-Sanchez et al. (2007) also obtained lower male broiler breeder weight when feeding diets with $12 \%$ crude protein (CP) compared with diets with 17\% CP. Rostagno et al. (2011) recommend CP levels of 11.7 to $12.6 \%$ for male broiler breeders.

Fertility consistently improved when roosters were fed the male-specific diet compared with the female diet. French (2013) observed that fertility improved between 0.4 and $1.1 \%$ during the production cycle, but the greatest benefit was obtained after 53 weeks of age, when roosters were fed a different diet from that of females. In addition, the male-specific diet (treatment 2) increased the persistency of fertility. In a study carried out in The Netherlands, male broiler breeders were fed diets with three different CP levels $(13.1,14.2,15.2 \%)$ and one single energy level $(2,700$ $\mathrm{kcal})$, and the best fertility persistence was obtained with the diet containing $13.1 \%$ protein (French, 2013). In the present study, roosters fed the female diet with $15 \%$ CP (treatment 1) presented worse fertility than treatment 2 males. This was also observed by Hocking
(1989), who indicated that the CP level of female diets (16\% CP) negatively affects the fertility of 40 to 65-week-old roosters. According to Tardin (1990) feeding roosters a $16 \%$ protein diet increases feeding costs in 7 to $11 \%$ compared with diets containing $12 \%$ CP.

\section{CONCLUSIONS}

Feeding male broiler breeders a specific diet has beneficial effects on body weight control and on egg hatchability and fertility. This demonstrates that supplying a specific diet for male broiler breeders is economically viable, as it increases the number of chicks hatched.

\section{REFERENCES}

Adda TRBL de. Embrio-diagnóstico. In: Macari M, Gonzales E, editores Manejo da incubação. $2^{a}$ ed. Jaboticabal, São Paulo: FACTA; 2003. p. 500-512.

Barbato GF. Genetic relationships between selection for growth and reproductive effectiveness. Poultry Science 1999;78:444-452.

Borges CAQ, Rostagno HS, Silva JHV, Albino LFT, Torres CAA, Filho JJ, Ribeiro MLG. Exigências de energia e composição da carcaça de galos reprodutores pesados em função do consumo energético na fase de reprodução. Revista Brasileira de Zootecnia 2006a;35(5):1978-1984.

Borges CAQ, Rostagno HS, Silva JHV, Albino LFT, Torres CAA, Filho JJ, Ribeiro MLG. Exigências de proteína e composição da carcaça de galos reprodutores 21 a 61 semanas. Revista Brasileira de Zootecnia 2006b;35(5):1971-1977.

Creel LH, Maurice D, Bridges WC, Grimes LW. A model to describe and predict post-peak changes in broiler hatchability. Journal Applied Poultry Research 1990;7:85-89.

Duncan IJH, Hocking PM, Seivewright, E. Sexual behavior and fertility in broiler breeder domestic fowl. Applied Animal Behaviour Science 1990;26:1-12.

Fernandes EA, Fagundes NS. Nutrição da matriz. In: Macari M, Gonzales E, Patrício IS, Martins PL, Nääs, IA, editores. Manejo da Incubação $3^{a}$ ed. Jaboticabal, São Paulo: FACTA; 2013. p.203-219.

French N. Fatores que afetam a fertilidade de machos e fêmeas. In: Macari M, Gonzales E, Patrício IS, Martins PL, Nääs, IA, editores. Manejo da Incubação. $3^{\text {aed }}$. Jaboticabal: FACTA; 2013. p. 315-320.

Goerzen PR, Julsrud WL, Robinson FE. Duration of fertility in ad libitum and feed-restricted caged broiler breeders. Poultry Science 1996;75:962965 .

Hocking PM. Effect of dietary crude protein concentration on semen yield and quality in male broiler breeder fowls. British Poultry Science 1989;30:935-945

Hocking PM. The relationships between dietary crude protein, body weight, and fertility in naturally mated broiler breeder males. British Poultry Science 1990;31:743-757

Hocking PM. Influence of the male on the decline of fertility with age in broiler breeder flocks. In: J. P. Brillard, editor. Control of fertility in domestic birds. Paris: Les Colloques de L'INRA; 1990. v.54, p.213-218. 
Hocking PM, Bernard R. Effects of the age of male and female broiler breeders on sexual behavior, fertility, and hatchability of eggs. British Poultry Science 2000;41:370-376.

Leeson S. Energia para reprodutoras pesadas. Anais da Conferência Apinco de Ciência e Tecnologia Avícolas; Simpósio Internacional sobre Nutrição de Aves; 1999; Campinas, São Paulo. Brasil. Campinas: FACTA, 1999. p.25-39.

Leeson S, Summers JD. Broiler breeder production. Guelph: University Books; 2000. 339 p.

North MO, Bell DD. Commercial chicken production mannual. $4^{\text {th }}$ ed. Amsterdam: Van Nostrand Reinhold; 1990. 913p.

Pearson RA, Herron, KM. Effects of energy and protein allowances during lay on the reproductive performance of broiler breeder hens. British Poultry Science 1981;22:227-239.

Reddy RP, Kelly J. Fatores de manejo que determinam ótima produtividade em reprodutores machos. Anais do Congresso Brasileiro de Avicultura; 1991; Brasília,DF. Brasil. 1991. Brasília,DF: SBZ; 1991. p.71-88.

Romero-Sanchez H, Plumstead PW, Brake J. Effect of plane of nutrition at the same feed intake on body weight and carcass characteristics of broiler breeder males. Poultry Science 2004;83:104.
Romero-Sanchez H, Plumstead PW, Brake J. Feeding broiler breeder males. 1. Effect of feeding program and dietary crude protein during rearing on body weight and fertility of broiler breeder males. Poultry Science 2007;86:168-174

Rostagno HS. Tabelas brasileiras para suínos e aves: composição de alimentos e exigências nutricionais. $3^{\text {a }}$ ed. Viçosa (MG): Universidade Federal de Viçosa, Departamento de Zootecnia; 2011. 252p.

SAS Institute. SAS/STAT® 9.2 user's guide. Version 9.2. Cary (NC); 2008.

Sexton KJ, Renden JA, Marple DN, Kempainen RJ. Effects of dietary energy on semen production, fertility, plasma testosterone, and carcass composition of broiler breeder males in cages. Poultry Science 1989; 68:1688-1694.

Tardin A.C. Novos conceitos de alimentação de matrizes pesadas. Reunião Anual da Sociedade Brasileira de Zootecnia;1990; Campinas, São Paulo. Brasil. Campinas: Sociedade Brasileira de Zootecnia, 1990. p.36-70.

Walsh TJ, Brake J. The effect of nutrient intake during rearing of broiler breeder females on subsequent fertility. Poultry Science 1997;76:297305. 
